\title{
Rutin in herbs and infusions: screening of new sources and consumption estimation
}

\author{
Adriana Dillenburg MEINHART ${ }^{1,2 *}$ (D), Fernanda Mateus DAMIN ${ }^{1}$, Lucas CALDEIRÃOํㅜ , José TEIXEIRA-FILHO ${ }^{3}$, \\ Helena Teixeira GODOY ${ }^{1}$
}

\begin{abstract}
Rutin has shown promising results in reducing various human diseases. However, many plants consumed in Brazil do not have their rutin content reported in the literature yet. More than eighty plants were analyzed using aqueous (popularly known as tea) and ethanolic extraction (employed in commercial rutin purification) by liquid chromatography. Rutin was found in 47 samples when ethanol extraction was used. Echinodorus grandiflorus had the highest content $\left(14,878.7 \mathrm{mg}^{\left.1000 \mathrm{~g}^{-1}\right) \text {, followed }}\right.$ by Sambucus nigra, Drimys winteri and Taraxacum officinale. In aqueous infusion, Echinodorus grandiflorus, Sambucus nigra, Drimys winteri and Ruta graveolens presented the highest levels of rutin, ranging from 15.5 to $29.7 \mathrm{mg}$ of rutin in $300 \mathrm{~mL}$ of infusion from $2 \mathrm{~g}$ of the plant. Echinodorus grandiflorus, Sambucus nigra, Drimys winteri, Taraxacum officinale and Ruta graveolens presented a high amount of flavonoid and might be good alternatives as ingredients in food and pharmaceuticals in order to obtain health benefits.
\end{abstract}

Keywords: tea; HPLC; phenolic compounds; quantification; bioactive.

Practical Application: This study presented new sources of rutin for enrichment of diets and commercial purification.

\section{Introduction}

Rutin belongs to the family of flavonoids and could be more specifically classified as a flavonol. It is a molecule of quercetin with the addition of a disacchari de (rhamnose and glucose). Due to rutin's pharmacological activities, associated with different properties, such as anti-inflammatory and antioxidant actions, it became of great importance for the pharmaceutical industry, and many drugs registered worldwide contains rutin in their composition (Abarikwu et al., 2017; Chua, 2013; Ganeshpurkar \& Saluja, 2016; Ghorbani, 2017).

Chen et al. (2014) demonstrated that rutin is a potential protective agent against acute lung injury caused by interaction with lipopolysaccharides. The study shows its effect in the inflammatory action in the lungs through inhibition of the activation of MIP-2 (inflammatory protein) and MMP-9 (endopeptidase). The anti-inflammatory effect of rutin was also observed in cases of chronic colitis (Mascaraque et al., 2014). Choi et al. (2015) studied the antithrombotic effect of rutin in vitro and in vivo, suggesting that it could, pottentially, be used in the treatment of cardiovascular diseases by reducing thrombin activity, inhibiting platelet aggregation and fibrin coagulation.

Kaur \& Muthuraman (2016) found positive effects when they used rutin to treat renovascular hypertension caused by renal ischemia. Some researchers showed promising results for Alzheimer's treatment, in which rutin was correlated with beneficial effects against the neurotoxicity of $A \beta$ (amyloid beta peptide), besides reducing levels of oxidative stress and brain inflammation (Moghbelinejad et al., 2014; Xu et al., 2014).
Pan et al. (2014) studied the influence of rutin in the treatment of cholestatic liver lesions and Wang et al. (2016) the antifibrotic action on neuropathy in rats. They both concluded that rutin consumption resulted in significant improvement in the studied diseases. Rutin was also considered effective in alleviating the toxic effect of ethanol in neural cells through the activation of ALDH2 (aldehyde dehydrogenase 2) that converts acetaldehyde into acetic acid (Song et al., 2014), besides contributing positively with spinal cord injury treatment (Wu et al., 2016), inhibiting effects of thyroid hormones in rats with hyperthyroidism (Panda \& Kar, 2014) and improving neuropathy caused by diabetes (Tian et al., 2016).

Rutin has also been studied for its use in cosmetics for the production of sunscreen, and the result was promising compared to traditional sunscreens (Kamel \& Mostafa, 2015).

In Brazil the use of vegetables in infusions is associated with traditional knowledge from native and popular culture and has more recently expanded thanks to miscegenation with emigrants from Africa, Europe and Asia (Bolson et al., 2015). Despite the significant amount of plants used in infusions in Brazil, there are few data on rutin content in these plants and in their aqueous infusions.

Therefore, this work aimed to quantify rutin in more than 80 plants commonly used by the population, taking into consideration the extraction of this compound using aqueous infusion, popularly known as tea, which is the common method of consumption, as well as extraction with ethanol (largely 
employed in commercial purification of rutin), considered a green solvent due to its low cost, toxicity and environmental impact.

\section{Materials and methods}

\subsection{Samples and reagents}

The plants were obtained in fairs and public markets of Campinas and Americana, SP, Brazil. Each plant has been acquired from three suppliers in dried form, just like it is commercialized. The plants were identified with both the popular and scientific names, according to the product label description and to the Brazilian Official Pharmacopoeia (Brasil, 2010) and when its name was not found in the publication, we cited their scientific names given by the suppliers. None of the analyzed plants has any consumption restriction according to the Brazilian legislation (Brasil, 2014). This study has access to Brazilian genetic patrimony and was registered under the Ministério do Meio Ambiente (protocol number A3414AD).

The standard of the rutin was obtained from Biopurify (Chengdu, China). Stock solutions were prepared in HPLC grade methanol (J.T. Baker, Brazil), at a concentration of $1 \mathrm{mg} \mathrm{mL}^{-1}$, and stored at $-80^{\circ} \mathrm{C}$. Formic acid was purchased from Merck (Brazil), HPLC grade acetonitrile from J.T. Baker (Brazil) and ethanol absolute from Synth (Brazil). Ultrapure water was obtained using Milli- ${ }^{\circledR}$ system (Millipore Corporation, France). All solutions were filtered in $0.22 \mu \mathrm{m}$ PVDF membranes (Millipore Corporation, France).

\subsection{Sample preparation}

Approximately $40 \mathrm{~g}$ of sample from each supplier were weighed, homogenized and ground in a hammermill (Marconi TE 600, Brazil), with a 200 mesh sieve. Samples containing barks, stalks, stems and tubercles were reduced in size with a knife before grinding.

For rutin extraction using solvent, the method was based on the study of Meinhart et al. (2017) where $0.5 \mathrm{~g}$ of ground sample were weighed in tubes with lid and $15 \mathrm{~mL}$ of solution added containing $74 \%$ of water and $26 \%$ of ethanol. Tubes were hermetically sealed and heated in water bath at $60{ }^{\circ} \mathrm{C}$, under agitation ( $240 \mathrm{rpm}$ ) for 22 minutes. Then the volume was adjusted to $100 \mathrm{~mL}$, the extracts were filtered and injected.

We weighed $2 \mathrm{~g}$ of sample (an equivalent to a tea sachet) to prepare the aqueous infusions (teas), added $300 \mathrm{~mL}$ of boiling water and then let them remain still for 16 minutes. After that, the mixture was cooled, its volume adjusted to $500 \mathrm{~mL}$, the extract was filtered and injected. Each extraction was performed three times. The method was based on da Silveira et al. (2017).

\subsection{Method for analysis of rutin}

All analyses were carried out using ultra performance liquid chromatography employing a Waters Acquity UPLC ${ }^{\circledR}$ (Thermo, USA) equipament, with a Kinetex ${ }^{\circledR} \mathrm{C} 18$ column (Phenomenex, USA) - $100 \mathrm{~mm}$ length, $2.1 \mathrm{~mm}$ i.d. and $1.7 \mu \mathrm{m}$ particle size. The column temperature was maintained at $30^{\circ} \mathrm{C}$. The mobile phase consisted of acidified water (formic acid $0.1 \%, \mathrm{pH} 2.4$ ) - A and acetonitrile - B. The linear gradient started with $100 \%$ A with linear decrease up to $92 \% \mathrm{~A}$ at 10 minutes, continuing with linear gradient until it reached $70 \% \mathrm{~A}$ at 14 minutes, which was held constant until minute 15 . For cleaning the column, a new linear gradient started from 15 to 16 minutes until it reached $100 \%$ B at 16 minutes, which was held for 1 minute. From 17 minutes to 23 minutes the column was reconditioned with $100 \% \mathrm{~A}$. The flow rate was $0.3 \mathrm{~mL} \mathrm{~min}^{-1}$ and the injection volume was $10 \mathrm{uL}$. The method was based on studies carried out by Van Hung \& Morita (2008) and Meinhart et al. (2017). Identification of the compounds was made comparing standards through retention time, absorption spectrum of the diode arrangement detector (DAD) with a wavelength of $325 \mathrm{~nm}$ and through co-chromatography (spiked sample). Quantification was carried out using external calibration curve.

The method was validated for limit of detection and limit of quantification (three times and six times the signal to noise ratio, respectively). The analytical curve was constructed in 7 equidistant concentrations, randomly repeated three times, starting with the limit of quantification and ending with the concentration up until linearity was ensured through the evaluation of the models for lack of fit, and ANOVA regression significance was carried out using Statistica 7.0 (Statsoft, USA). Precision was analyzed between days and on the same day. On the same day it was analyzed through 10 successive determinations, which were repeated for 3 days to determine the precision between days. Precision on the same day and between days was carried out in 3 levels, including the limit of quantification, the intermediate and the maximum point of the analytical curve $(n=10$ for each). Analytical trueness for the ethanol-based extraction was evaluated through recovery in the same three levels as in the precision assay ( $\mathrm{n}=3$ for each level).

\section{Results and discussion}

\subsection{Validation of analytical methodology}

The method of analysis has been properly validated showing an adequate linearity, with $\mathrm{F}$ values for lack of fit smaller than the critical values of $\mathrm{F}$, with $95 \%$ of confidence level. The limits of quantification were $0.05 \mathrm{mg} \mathrm{L}^{-1}$ and the coefficients of variation were a maximum value of $5.4 \%$ for precision testings and recovery between 98.3 and $104.7 \%$. The parameters are in accordance with the limits established by IUPAC (International Union of Pure and Applied Chemistry, 2002) and ANVISA (Brasil, 2017), indicating that the method is recommended to perform quantitative analysis with adequate analytical certainty. In Table 1, there are figures of merit for the analytical method.

\subsection{Extraction using ethanol for commercial purification}

Table 2 shows rutin content in the plants studied using ethanol extraction and aqueous infusion, expressed in $\mathrm{mg} 1000 \mathrm{~g}^{-1}$. Results were also expressed in $\mathrm{mg}$ of rutin in $300 \mathrm{~mL}$ of aqueous infusion, considering its consumption when the tea is prepared with a sachet (around $2 \mathrm{~g}$ ). Figure 1 shows the chromatograms of the winter's bark and chapéu de couro samples.

Forty-five of the eighty-three plants analyzed showed quantifiable

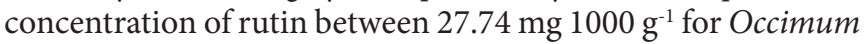


Table 1. Figures of merit for the analysis using ultra performance liquid chromatography for determination of rutin in Brazilian plants.

\begin{tabular}{|c|c|c|}
\hline Parameters & & Rutin \\
\hline Linear range $\left(\mathrm{mg} \mathrm{L}^{-1}\right)$ & & 0.05 to 35.0 \\
\hline Model & & $y=3,511.5 x-155.61$ \\
\hline Linear model adjustment $(\mathrm{F})^{(1)}$ & & 2.17 \\
\hline \multirow[t]{3}{*}{ Precision on the same the day in relative standard deviation $(\mathrm{n}=10)$} & Level $1^{(2)}$ & $5.40 \%$ \\
\hline & Level 2 & $2.67 \%$ \\
\hline & Level 3 & $3.09 \%$ \\
\hline \multirow[t]{3}{*}{ Precision between days in relative standard deviation $(\mathrm{n}=10)$} & Level 1 & $0.59 \%$ \\
\hline & Level 2 & $1.52 \%$ \\
\hline & Level 3 & $0.28 \%$ \\
\hline Limit of detection $\left(\mathrm{mg} \mathrm{L}^{-1}\right)$ & & 0.025 \\
\hline Limit of quantification $\left(\mathrm{mg} \mathrm{L}^{-1}\right)$ & & 0.05 \\
\hline \multirow[t]{3}{*}{ Recovery ( $\mathrm{n}=3$ for each level) } & Level 1 & $104.71 \%$ \\
\hline & Level 2 & $98.28 \%$ \\
\hline & Level 3 & $99.56 \%$ \\
\hline
\end{tabular}

${ }^{(1)}$ The model is adequately adjusted when calculated F is smaller than critical F (3.49) with $95 \%$ of confidence; ${ }^{(2)}$ Level 1, 2 and 3 concentrations: limit of quantification, intermediate and the maximum point of linear range of analytical curve.

Table 2. Rutin content in plants consummed in Brazil.

\begin{tabular}{|c|c|c|c|c|c|c|}
\hline \multirow{2}{*}{ Scientific Name } & \multirow{2}{*}{ Popular Name } & \multirow{2}{*}{$\begin{array}{l}\text { Parts of the } \\
\text { plant }\end{array}$} & $\begin{array}{l}\text { Ethanol Extration } \\
\left(\mathrm{mg} 1000 \mathrm{~g}^{-1}\right)\end{array}$ & 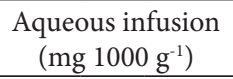 & \multirow{2}{*}{$\begin{array}{c}\text { Rutin } \\
\text { in aqueous } \\
\text { infusion } \\
\left(\mathrm{mg} 300 \mathrm{~mL}^{-1}\right)\end{array}$} & \multirow{2}{*}{$\begin{array}{l}\% \text { of } \\
\text { infusion } \\
\text { extraction } \\
\text { in relation } \\
\text { to ethanol } \\
\text { extraction }\end{array}$} \\
\hline & & & Mean \pm RSD & Mean \pm RSD & & \\
\hline Rosmarinus officinalis & Rosemary & Leaves & nd & nd & nd & - \\
\hline Lavandula officinalis & Green Lavender & Flowers & nd & nd & nd & - \\
\hline $\begin{array}{l}\text { Adiantum capillus- } \\
\text { veneris }\end{array}$ & Maidenhair & Leaves & nd & nd & nd & - \\
\hline Cordia verbenácea & Black Sage & Leaves, thalli & nd & nd & nd & - \\
\hline Myroxylon peruiferum & Bálsamo do norte & Bark & nd & nd & nd & - \\
\hline Cirsium vulgare & Common Thistle & Leaves, thalli & nd & nd & nd & - \\
\hline Rhamnus purshiana & Buckthorn & Bark & nd & nd & nd & - \\
\hline Erytroxylon catuaba & Catuaba & Bark & nd & nd & nd & - \\
\hline Equisetum arvensis & Horsetail & Leaves, thalli & nd & nd & nd & - \\
\hline Hydrocotyle asiatica & Centella Asiatica & Leaves, thalli & nd & nd & nd & - \\
\hline Polygonum acre & Water Pepper & Leaves, thalli & nd & nd & nd & - \\
\hline Pimpinella anisum & Anise & Flowers & nd & nd & nd & - \\
\hline Eucaliptus globulos & Eucalyptus & Leaves, thalli & nd & nd & nd & - \\
\hline Verbena bonariensis & Vervain & Stem & nd & nd & nd & - \\
\hline Panax ginseng & Ginseng & Roots & nd & nd & nd & - \\
\hline
\end{tabular}

RSD: relative standard deviation $(\mathrm{n}=3)$, nd: not detected. 
Table 2. Continued...

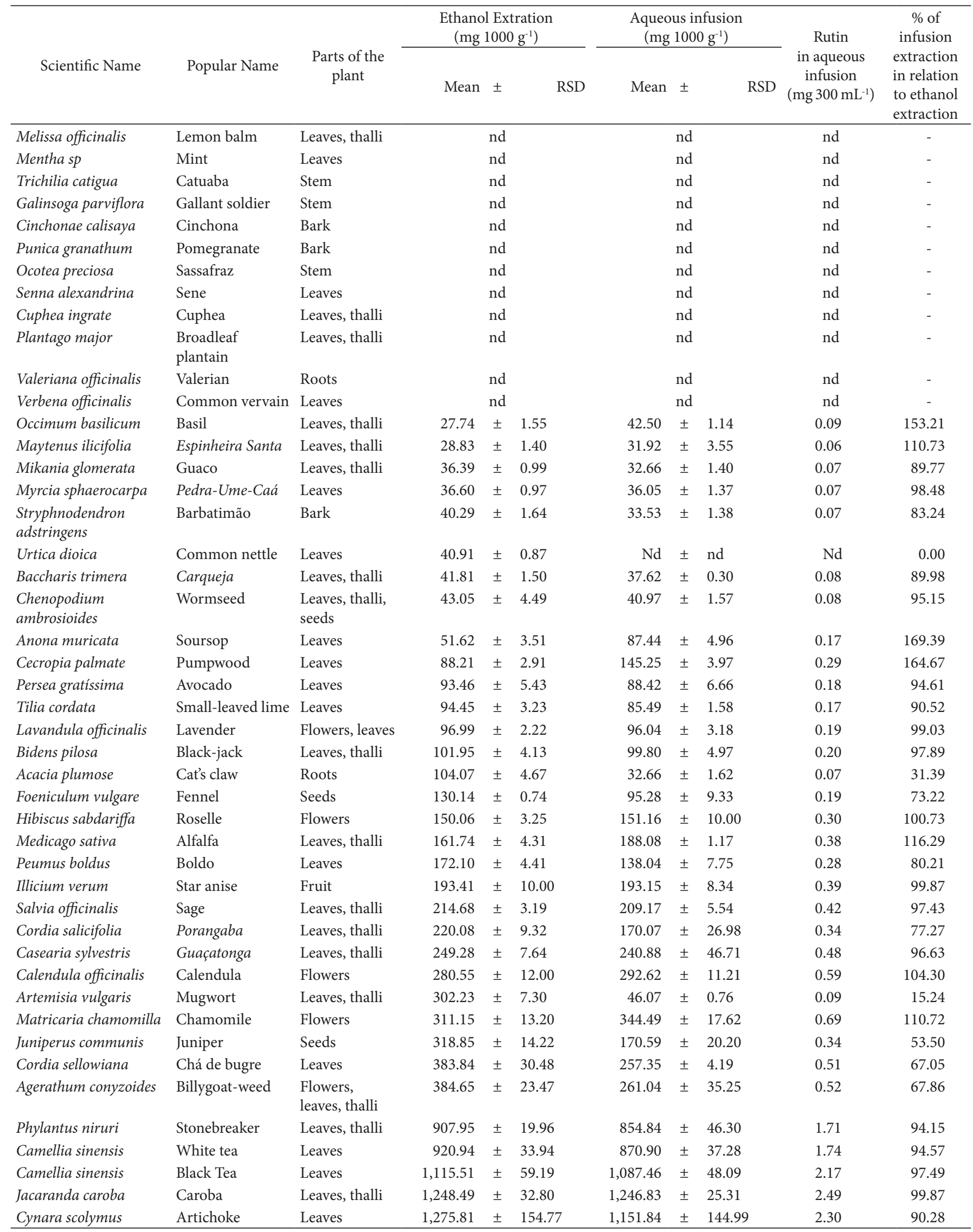

RSD: relative standard deviation $(n=3)$, nd: not detected. 
Table 2. Continued...

\begin{tabular}{|c|c|c|c|c|c|c|c|c|c|c|}
\hline \multirow{2}{*}{ Scientific Name } & \multirow{2}{*}{ Popular Name } & \multirow{2}{*}{$\begin{array}{c}\text { Parts of the } \\
\text { plant }\end{array}$} & \multicolumn{3}{|c|}{ 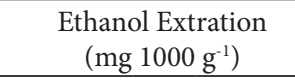 } & \multicolumn{3}{|c|}{$\begin{array}{l}\text { Aqueous infusion } \\
\left(\mathrm{mg} 1000 \mathrm{~g}^{-1}\right)\end{array}$} & \multirow{2}{*}{$\begin{array}{c}\text { Rutin } \\
\text { in aqueous } \\
\text { infusion } \\
\left(\mathrm{mg} 300 \mathrm{~mL}^{-1}\right)\end{array}$} & \multirow{2}{*}{$\begin{array}{l}\text { \% of } \\
\text { infusion } \\
\text { extraction } \\
\text { in relation } \\
\text { to ethanol } \\
\text { extraction }\end{array}$} \\
\hline & & & Mean & \pm & RSD & Mean & \pm & RSD & & \\
\hline Camellia sinensis & Green tea & Leaves & $1,334.83$ & \pm & 102.98 & $1,124.15$ & \pm & 9.62 & 2.25 & 84.22 \\
\hline Bauhinia forficate & Cow's Foot & Leaves & $1,540.17$ & \pm & 27.39 & $1,318.32$ & \pm & 69.95 & 2.64 & 85.60 \\
\hline Arctium lappa & Greater burdock & Leaves, thalli & $1,631.90$ & \pm & 123.86 & $2,408.32$ & \pm & 324.25 & 4.82 & 147.58 \\
\hline Sida cordifolia & Flannel weed & Leaves & $1,733.38$ & \pm & 31.82 & $1,621.73$ & \pm & 48.47 & 3.24 & 93.56 \\
\hline Boehmeria caudate & Assa-Peixe & Leaves, thalli & $2,943.22$ & \pm & 302.56 & $4,714.01$ & \pm & 468.19 & 9.43 & 160.16 \\
\hline Ilex paraguariensis & Yerba mate & Leaves, thalli & $4,645.26$ & \pm & 313.90 & $4,120.79$ & \pm & 37.45 & 8.24 & 88.71 \\
\hline Ruta graveolens & Rue & Leaves, thalli & $8,291.50$ & \pm & 210.92 & $7,763.32$ & \pm & 398.49 & 15.53 & 93.63 \\
\hline Taraxacum officinale & Dandelion & Leaves, thalli & $9,148.51$ & \pm & 908.11 & & nd & & nd & 0.00 \\
\hline Drimys winteri & Winter's bark & Bark & $9,788.70$ & \pm & 664.44 & $7,591.96$ & \pm & $1,167.61$ & 15.18 & 77.56 \\
\hline Sambucus nigra & Sabugueiro & Flores & $11,576.75$ & \pm & 519.61 & $8,316.32$ & \pm & 145.15 & 16.63 & 71.84 \\
\hline $\begin{array}{l}\text { Echinodorus } \\
\text { grandifloras }\end{array}$ & Chapéu de couro & Leaves, thalli & $14,878.61$ & \pm & 230.68 & $14,849.45$ & \pm & 44.37 & 29.70 & 99.80 \\
\hline
\end{tabular}

RSD: relative standard deviation $(\mathrm{n}=3)$, nd: not detected.

basilicum and 14,878.61 mg $1000 \mathrm{~g}^{-1}$ for Echinodorus grandiflorus. Besides, Echinodorus grandiflorus, Sambucus nigra, Drimys winteri, Taraxacum officinale and Ruta graveolens should be highlighted

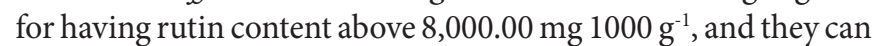
be considered a potencial source of rutin. Ilex paraguariensis is widely consumed in Brazil as infusion and is highlighted by its high phenolic content, especially those derived from caffeic acid (Silveira et al., 2016; Marques \& Farah, 2009). Regarding its rutin content, it was found 4,645.26 mg $1000 \mathrm{~g} \mathrm{~g}^{-1}$ and, although it had the lowest content among the above-mentioned plants, it has a higher content than the popular green tea $\left(1,344.83 \mathrm{mg} 1000 \mathrm{~g} \mathrm{~g}^{-1}\right)$,

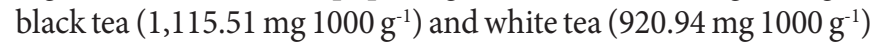
from Camellia sinensis.

In the literature, there are works which have reported the quantification of rutin in Sambucus nigra and Ruta graveolens flowers that were similar to the present work, or even superior (Dawidowicz \& Wianowska, 2009; Mohamed \& Ibrahim, 2012; Ueng et al., 2015). Differences in this study's results compared to the literature can be explained by the growing conditions of the plants, climate and botanical variety, besides the use of other parts of the plant such as the stem, which has a lower concentration of rutin.

We have not found, so far, studies that determined the concentration of rutin in Echinodorus grandiflorus and Taraxacum officinale.

The arboreal species Dimophandra mollis is often used for the commercial obtainment of rutin in Brazil, and it provides the yield of $8 \mathrm{~g}$ per $100 \mathrm{~g}$ of the fava pericarp (Becho et al., 2009). Comparing the yielding and the crop characteristics, Echinodorus grandifloras presents itself as an excellent source for the commercial obtainment due to its high yield (14.9 g per kilo of leaf) and because it is a ground plant, with fast growth, easy to handle and adapted to tropical, subtropical and temperate climates.

\subsection{Extraction using aqueous infusion for human consumption}

The plants which presented higher content of rutin transferred from the plant to the aqueous infusion were Echinodorus grandifloras

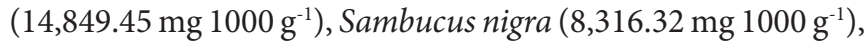
Ruta graveolens $\left(7,763.32 \mathrm{mg} 1000 \mathrm{~g}^{-1}\right)$ and Drimys winteri $\left(7,591.96 \mathrm{mg} 1000 \mathrm{~g}^{-1}\right)$.

The percentage of extraction of seventeen plants ranged from 90 to $99.99 \%$ when hot water was used compared to ethanol extraction. The percentage of extraction of seven plants ranged from 80 to $89.99 \%$, four from 70 to $79.99 \%$, and two from 60 to $69.99 \%$. Acacia plumosa, Artemisia vulgaris and Juniperus communis percentages were lower than $60 \%$, whereas only Taraxacum officinale and Urtica dioica had non-quantifiable results of rutin using infusion.

Although Taraxacum officinale contains a high amount of rutin when extracted using solvent, it did not have a quantifiable content when using aqueous infusion. The transfer rate of compounds from the leaves to the infusion may be affected by the amount of leaves or stems used, particle size, water volume, emperature, presence or absence of stirring and the duration of infusion (Astill et al., 2001; Nishiyama et al., 2010), showing the necessity of optimizing the way aqueous infusion is prepared to increase the migration of this compound.

On the other hand, nine of the forty-five samples that had quantifiable content of rutin in ethanol extraction had a higher concentration when extracted using only aqueous infusion. Calendula officinalis concentration was $4 \%$ higher in aqueous infusion, Matricaria chamomilla and Maytenus ilicifolia concentration was $10 \%$ higher, Medicago sativa 16\%, Arctium lappa 47\%, Occimum basilicum 53\%, Boehmeria caudata 60\%, Cecropia palmata 64\% and Anona muricata 69\%.

The results show that when we compare ethanol extraction and aqueous infusion, more elaborate exploratory studies are necessary for each plant in order to obtain the maximum extraction of 

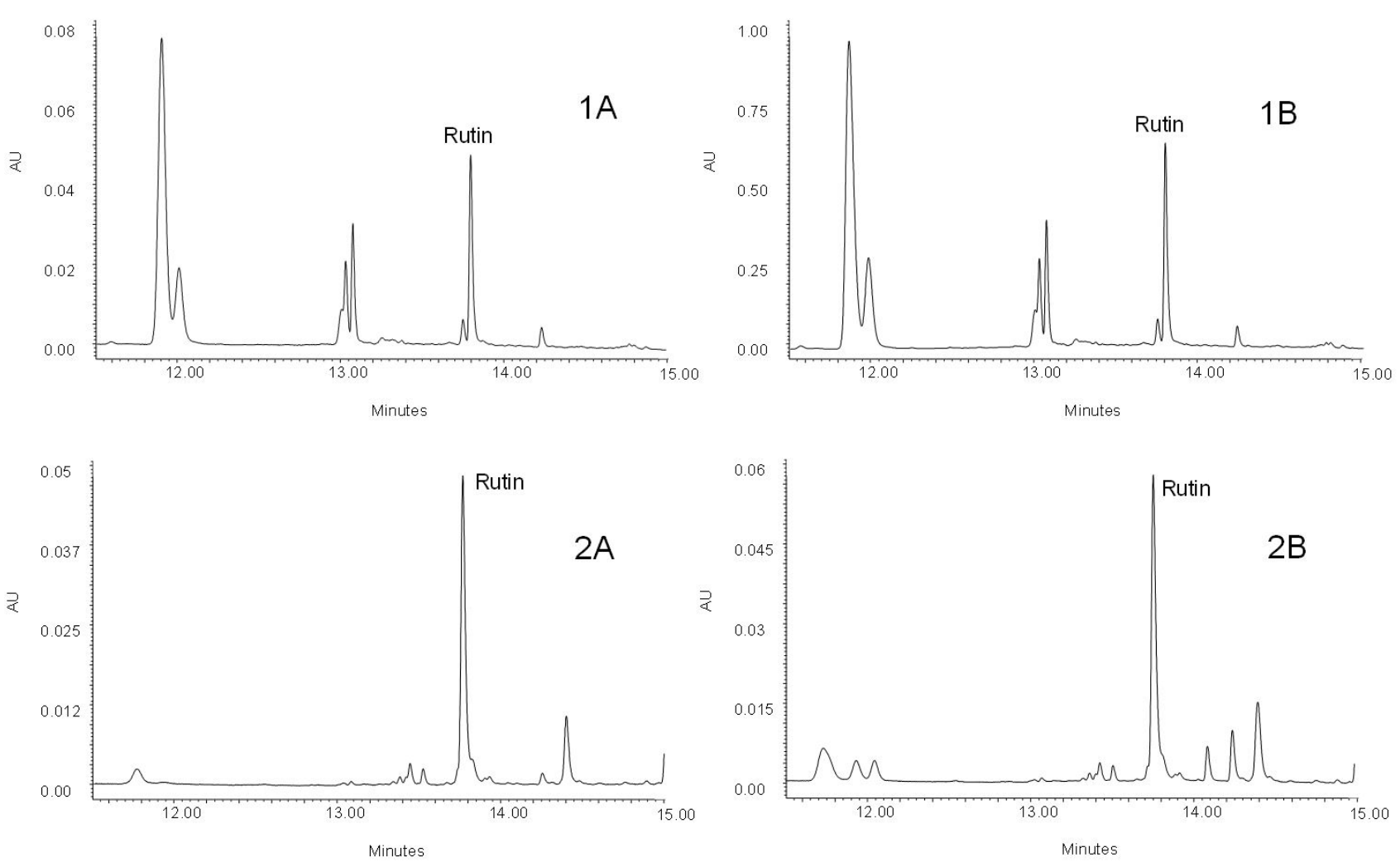

Figure 1. Chomatogram of rutin in Winter's bark (Drimys winteri) - ethanol:água (1A) and aqueous infusion (1B) and Chapéu de couro (Echinodorus grandifloras) - ethanol:água $(2 \mathrm{~A})$ and aqueous infusion (2B). UPLC analisys conditions: $\mathrm{C} 18$ column, column oven at $30^{\circ} \mathrm{C}$, mobile phase $(0.3 \mathrm{~mL}$ min -1$)$ : water acidified with formic acid $(0.1 \%, \mathrm{pH} 2.4)-\mathrm{A}$ and acetonitrile $-\mathrm{B}$ with a linear gradient beginning at $100 \% \mathrm{~A}$, with a linear decrease to $92 \% \mathrm{~A}$ at 10 minutes, following the linear gradient until $70 \% \mathrm{~A}$ at 14 minutes, which was kept constant until 15 minutes.

rutin. Several parameters may influence the extraction difference observed when the samples were extracted only with water or water: ethanol mixture. One of the most important factors is the capacityof the extracting solution to permeate the plant structure and solubilize the compound. Such effect may be altered by the individual or synergistic action of the composition of the extraction solution (whose polarity change influences the intensity of the attractive forces between the rutin molecules and the extraction solution), agitation, particle size, volume of extraction and, in particular, the composition of the plant matrix (which may cause physical barrier effects or competitive effects among the other matrix compounds - as seen in Figures 1A and 1B) (Astill et al., 2001; Silveira et al., 2014; Nishiyama et al., 2010; Damoraran \& Parkin, 2019; Martins et al., 2013). To further elucidate the chemical effects that occur in each plant, future species-specific optimization studies may be relevant.

Table 2 gives the concentration of rutin per $300 \mathrm{~mL}$ of beverage prepared by infusion from $2 \mathrm{~g}$ of plant to determine rutin consumption per portion of beverage. Five infusions with higher levels of rutin were Ilex paraguarienses $(8.24 \mathrm{mg})$, Boehmeria caudata $(9.43 \mathrm{mg})$, Drimys winteri $(15.18 \mathrm{mg})$, Ruta graveolens (15.53 mg), Sambucus nigra (16.63 mg) and Echinodorus grandiflorus $(29.70 \mathrm{mg})$. In order to consume the same amount of rutin present in $300 \mathrm{~mL}$ of Echinodorus grandiflorus beverage, a person must consume $600 \mathrm{~mL}$ of beverage made of Sambucus nigra, Drimys winteri or Ruta graveolens, approximately $1000 \mathrm{~mL}$ of Ilexparaguarienses infusion, approximately $5200 \mathrm{~mL}$ of white tea (Camellia sinensis) infusion or $46000 \mathrm{~mL}$ of Lavandula officinalis infusion.

Compared to other foods and beverages, the consumption of $300 \mathrm{~mL}$ of Echinodorus grandiflorus aqueous infusion has a concentration of rutin equal to $400 \mathrm{~g}$ of cherry tomatoe (Sánchez-Rodríguez et al., 2012), $70 \mathrm{~g}$ of olives or $70 \mathrm{~mL}$ of olive oil (Yorulmaz et al., 2012), $550 \mathrm{~mL}$ of tangerine juice (Milella et al., 2011), $20 \mathrm{~g}$ of acerola (Nunes et al., 2011) or $6000 \mathrm{~mL}$ of red wine (Garaguso \& Nardini, 2015). These data show the potential of Echinodorus grandiflorus infusion as a source of rutin when compared to other foods and beverages.

Studies have reported that rutin offers beneficial effects on health, such as antihyperglycemic, in doses from $5.0 \mathrm{mg}$ per $\mathrm{kg}$ of body mass per day (Ghorbani, 2017). Thus, for a $70 \mathrm{~kg}$ adult, it is required a minimum intake of approximately $350.0 \mathrm{mg}$ of rutin, although this value can vary for each individual according to their metabolism and bioavailability of rutin (Lesser et al., 2015). The content is found in only $23.6 \mathrm{~g}$ of the plant, indicating that its consumption through dishes such as salads, seasoning or hot dishes is an easy way of obtaining the supply of this flavonol from alimentation. In addition, future studies may be useful to optimize the preparation form of the infusion, so that a greater amount of plant is used in relation to the volume of water, thus, allowing the ingestion of this quantity of rutin in a lower volume of infusion. 


\section{Conclusion}

This study highlights the importance of plants used in Brazil regarding rutin content, since it was found in 45 of 83 plants studied. The method of extraction using solvent (most used in commercial purification processes) or aqueous infusion (common method of consumption) has proved itself to be quite relevant regarding the content of rutin, since we observed a difference ranging from 0 to $169 \%$ among extractions, which shows the necessity of optimizing extraction for each source. The plants that showed the highest content of rutin in the aqueous infusions were Echinodorus grandiflorus, Sambucus nigra, Ruta graveolens and Drimys winteri (all above 7,000.00 mg of rutin per $1000 \mathrm{~g}$ of plants), emphasizing the potential of plants that had not been studied as new sources of rutin when compared to other foods and beverages, especially Echinodorus grandifloras

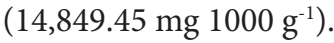

\section{Acknowledgements}

The authors would like to thank CAPES (Coordination for higher Education Staff Development) for their research support, a PNPD-CAPES post-doctorate scholarship (1267386), and a masters' scholarship; CNPq (Brazilian National Council for Scientific and Technological Development) for a doctorate scholarship (process no. 141944/2016-1) and Espaço da Escrita (Writing Space) in the State University of Campinas/SP, for translation services.

\section{References}

Abarikwu, S. O., Olufemi, P. D., Lawrence, C. J., Wekere, F. C., Ochulor, A. C., \& Barikuma, A. M. (2017). Rutin, an antioxidant flavonoid, induces glutathione and glutathione peroxidase activities to protect against ethanol effects in cadmium-induced oxidative stress in the testis of adult rats. Andrologia, 49(7), 1-12. http://dx.doi.org/10.1111/ and.12696. PMid:27562125.

Astill, C., Birch, M. R., Dacombe, C., Humphrey, P. G., \& Martin, P. T. (2001). Factors affecting the caffeine and polyphenol contents of black and green tea infusions. Journal of Agricultural and Food Chemistry, 49(11), 5340-5347. http://dx.doi.org/10.1021/jf010759+. PMid:11714326.

Becho, J. R. M., Machado, H., \& Guerra, M. O. (2009). Rutina estrutura, metabolismo e potencial. Revista Interdisciplinar de Estudos Experimentais, 1(1), 21-25.

Bolson, M., Hefler, S. R., Dall'Oglio Chaves, E. I., Gasparotto, A. Jr., \& Cardozo, E. L. Jr. (2015). Ethno-medicinal study of plants used for treatment of human ailments, with residents of the surrounding region of forest fragments of Paran?? Brazil. Journal of Ethnopharmacology, 161, 1-10. http://dx.doi.org/10.1016/j.jep.2014.11.045. PMid:25482361.

Brasil. Agência Nacional de Vigilância Sanitária. (2010). Farmacopéia brasileira (5. ed., Vol. 1). Brasília: Agência Nacional de Vigilância Sanitária.

Brasil. Agência Nacional de Vigilância Sanitária. (2014, May 13). Dispõe sobre o registro de medicamentos fitoterápicos e o registro e a notificação de produtos tradicionais fitoterápicos (RDC No 26 , de 13 de Maio de 2014). Diário Oficial [da] República Federativa do Brasil.

Brasil. Agência Nacional de Vigilância Sanitária. (2017, July 25). Dispõe sobre a validação de métodos analíticos e dá outras providências
(RDC No 166, de 24 de julho de 2017). Diário Oficial [da] República Federativa do Brasil, No. 141.

Chen, W. Y., Huang, Y. C., Yang, M. L., Lee, C. Y., Chen, C. J., Yeh, C. H., Pan, P. H., Horng, C. T., Kuo, W. H., \& Kuan, Y. H. (2014). Protective effect of rutin on LPS-induced acute lung injury via down-regulation of MIP-2 expression and MMP-9 activation through inhibition of Akt phosphorylation. International Immunopharmacology, 22(2), 409413. http://dx.doi.org/10.1016/j.intimp.2014.07.026. PMid:25091621.

Choi, J. H., Kim, D. W., Park, S. E., Lee, H. J., Kim, K. M., Kim, K. J., Kim, M. K., Kim, S. J., \& Kim, S. (2015). Anti-thrombotic effect of rutin isolated from Dendropanax morbifera Leveille. Journal of Bioscience and Bioengineering, 120(2), 181-186. http://dx.doi. org/10.1016/j.jbiosc.2014.12.012. PMid:25777266.

Chua, L. S. (2013). A review on plant-based rutin extraction methods and its pharmacological activities. Journal of Ethnopharmacology, 150(3), 805-817. http://dx.doi.org/10.1016/j.jep.2013.10.036. PMid:24184193.

Damoraran, S., \& Parkin, K. L. (2019). Química de alimentos de fennema (5. ed.). Porto Alegre: Artmed.

Dawidowicz, A. L., \& Wianowska, D. (2009). Application of the mspd technique for the hplc analysis of rutin in Sambucus nigra 1.: The linear correlation of the matrix solid-phase dispersion process. Journal of Chromatographic Science, 47(10), 914-918. http://dx.doi. org/10.1093/chromsci/47.10.914. PMid:19930805.

Ganeshpurkar, A., \& Saluja, A. (2016). The pharmacological potential of rutin. Saudi Pharmaceutical Journal PMid:28344465.

Garaguso, I., \& Nardini, M. (2015). Polyphenols content, phenolics profile and antioxidant activity of organic red wines produced without sulfur dioxide/sulfites addition in comparison to conventional red wines. Food Chemistry, 179, 336-342. http://dx.doi.org/10.1016/j. foodchem.2015.01.144. PMid:25722174.

Ghorbani, A. (2017). Mechanisms of antidiabetic effects of flavonoid rutin. Biomedicine and Pharmacotherapy, 96(October), 305-312. http://dx.doi.org/10.1016/j.biopha.2017.10.001. PMid:29017142.

International Union of Pure and Applied Chemistry - IUPAC. (2002). Harmonized guidelines for single-laboratory validation of methods of analysis (IUPAC Technical Report). Pure and Applied Chemistry, 74(5), 835-855.

Kamel, R., \& Mostafa, D. M. (2015). Rutin nanostructured lipid cosmeceutical preparation with sun protective potential. Journal of Photochemistry and Photobiology. B, Biology, 153, 59-66. http:// dx.doi.org/10.1016/j.jphotobiol.2015.09.002. PMid:26398812.

Kaur, S., \& Muthuraman, A. (2016). Therapeutic evaluation of rutin in two-kidney one-clip model of renovascular hypertension in rat. Life Sciences, 150, 89-94. http://dx.doi.org/10.1016/j.lfs.2016.02.080. PMid:26920631.

Lesser, M. N. R., Keen, C. L., \& Lanoue, L. (2015). Reproductive and developmental outcomes, and influence on maternal and offspring tissue mineral concentrations, of (-)-epicatechin, (+)-catechin, and rutin ingestion prior to, and during pregnancy and lactation in C57BL/6J mice. Toxicology Reports, 2, 443-449. https://doi. org/10.1016/j.toxrep.2015.01.003. PMID:28962380.

Marques, V., \& Farah, A. (2009). Chlorogenic acids and related compounds in medicinal plants and infusions. Food Chemistry, 113(4), 13701376. http://dx.doi.org/10.1016/j.foodchem.2008.08.086.

Martins, C. R., Lopes, W. A., \& Andrade, J. B. (2013). Organic compound solubility. Quimica Nova, 36(8), 1248-1255. http://dx.doi.org/10.1590/ S0100-40422013000800026.

Mascaraque, C., Aranda, C., Ocón, B., Monte, M. J., Suárez, M. D., Zarzuelo, A., Marín, J. J. G., Martínez-Augustin, O., \& de Medina, 
F. S. (2014). Rutin has intestinal antiinflammatory effects in the CD4+ CD62L+ T cell transfer model of colitis. Pharmacological Research, 90, 48-57. http://dx.doi.org/10.1016/j.phrs.2014.09.005. PMid:25281414.

Meinhart, A. D., Damin, F. M., Caldeirão, L., Silveira, T. F. F., Filho, J. T., \& Godoy, H. T. (2017). Chlorogenic acid isomer contents in 100 plants commercialized in Brazil. Food Research International, 99(Pt 1), 522-530. http://dx.doi.org/10.1016/j.foodres.2017.06.017. PMid:28784513.

Milella, L., Caruso, M., Galgano, F., Favati, F., Padula, M. C., \& Martelli, G. (2011). Role of the cultivar in choosing Clementine fruits with a high level of health-promoting compounds. Journal of Agricultural and Food Chemistry, 59(10), 5293-5298. http://dx.doi.org/10.1021/ jf104991z. PMid:21504146.

Moghbelinejad, S., Nassiri-Asl, M., Farivar, T. N., Abbasi, E., Sheikhi, M., Taghiloo, M., Farsad, F., Samimi, A., \& Hajiali, F. (2014). Rutin activates the MAPK pathway and BDNF gene expression on betaamyloid induced neurotoxicity in rats. Toxicology Letters, 224(1), 108113. http://dx.doi.org/10.1016/j.toxlet.2013.10.010. PMid:24148604.

Mohamed, M. A. H., \& Ibrahim, T. A. (2012). Enhanced in vitro production of Ruta graveolens L. coumarins and rutin by mannitol and ventilation. Plant Cell, Tissue and Organ Culture, 111(3), 335343. http://dx.doi.org/10.1007/s11240-012-0199-5.

Nishiyama, M. F., Costa, M. A. F., Costa, A. M., Souza, C. G. M., Bôer, C. G., Bracht, C. K., \& Peralta, R. M. (2010). Chá verde brasileiro (Camellia sinensis var assamica): efeitos do tempo de infusão, acondicionamento da erva e forma de preparo sobre a eficiência de extração dos bioativos e sobre a estabilidade da bebida. Food Science and Technology (Campinas), 30, 191-196. http://dx.doi.org/10.1590/ S0101-20612010000500029.

Nunes, R. S., Kahl, V. F., Sarmento, M. S., Richter, M. F., Costa-Lotufo, L. V., Rodrigues, F. A., Abin-Carriquiry, J. A., Martinez, M. M., Ferronatto, S., Ferraz, A. B., \& Silva, J. (2011). Antigenotoxicity and Antioxidant Activity of Acerola Fruit (Malpighia glabra L.) at Two Stages of Ripeness. Plant Foods for Human Nutrition (Dordrecht, Netherlands), 66(2), 129-135. http://dx.doi.org/10.1007/s11130011-0223-7. PMid:21503669.

Pan, P. H., Lin, S. Y., Wang, Y. Y., Chen, W. Y., Chuang, Y. H., Wu, C. C., \& Chen, C. J. (2014). Protective effects of rutin on liver injury induced by biliary obstruction in rats. Free Radical Biology \& Medicine, 73, 106-116. http://dx.doi.org/10.1016/j.freeradbiomed.2014.05.001. PMid:24815012.

Panda, S., \& Kar, A. (2014). Antithyroid effects of naringin, hesperidin and rutin in L-T4 induced hyperthyroid rats: Possible mediation through 5'DI activity. Pharmacological Reports, 66(6), 1092-1099. http://dx.doi.org/10.1016/j.pharep.2014.07.002. PMid:25443740.

Sánchez-Rodríguez, E., Ruiz, J. M., Ferreres, F., \& Moreno, D. A. (2012). Phenolic profiles of cherry tomatoes as influenced by hydric stress and rootstock technique. Food Chemistry, 134(2), 775-782. http:// dx.doi.org/10.1016/j.foodchem.2012.02.180. PMid:23107690.

Silveira, T. F. F., Meinhart, A. D., Souza, T. C. L., Cunha, E. C. E., Moraes, M. R., Teixeira, J. Fo., \& Godoy, H. T. (2017). Optimization of the preparation conditions of yerba mate tea beverage to maximize chlorogenic acids extraction. Plant Foods for Human Nutrition (Dordrecht, Netherlands), 72(2), 219-223. http://dx.doi.org/10.1007/ s11130-017-0613-6. PMid:28466135.

Silveira, T. F. F., Meinhart, A. D., Souza, T. C. L., Teixeira, J. Fo., \& Godoy, H. T. (2016). Phenolic compounds from yerba mate based beverages - A multivariate optimisation. Food Chemistry, 190, 1159-1167. http://dx.doi.org/10.1016/j.foodchem.2015.06.031. PMid:26213090.

Silveira, T., Meinhart, A. D., Ballus, C. A., \& Godoy, H. T. (2014). The effect of the duration of infusion, temperature, and water volume on the rutin content in the preparation of mate tea beverages: An optimization study. Food Research International, 60, 241-245. http:// dx.doi.org/10.1016/j.foodres.2013.09.024.

Song, K., Kim, S., Na, J. Y., Park, J. H., Kim, J. K., Kim, J. H., \& Kwon, J. (2014). Rutin attenuates ethanol-induced neurotoxicity in hippocampal neuronal cells by increasing aldehyde dehydrogenase 2 . Food and Chemical Toxicology, 72, 228-233. http://dx.doi.org/10.1016/j. fct.2014.07.028. PMid:25084483.

Tian, R., Yang, W., Xue, Q., Gao, L., Huo, J., Ren, D., \& Chen, X. (2016). Rutin ameliorates diabetic neuropathy by lowering plasma glucose and decreasing oxidative stress via Nrf2 signaling pathway in rats. European Journal of Pharmacology, 771, 84-92. http://dx.doi. org/10.1016/j.ejphar.2015.12.021. PMid:26688570.

Ueng, Y.-F., Chen, C.-C., Huang, Y.-L., Lee, I.-J., Yun, C.-H., Chen, Y.-H., \& Huang, C.-C. (2015). Effects of aqueous extract of Ruta graveolens and its ingredients on cytochrome P450, uridine and reduced nicotinamide adenine dinucleotide (phosphate) (NAD $(\mathrm{P})$ $\mathrm{H})$-quinone oxidoreductase in mice. Yao Wu Shi Pin Fen Xi, 23(3), 516-528. http://dx.doi.org/10.1016/j.jfda.2015.03.005. PMid:28911711.

Van Hung, P., \& Morita, N. (2008). Distribution of phenolic compounds in the graded flours milled from whole buckwheat grains and their antioxidant capacities. Food Chemistry, 109(2), 325-331. http://dx.doi. org/10.1016/j.foodchem.2007.12.060. PMid:26003354.

Wang, B., Liu, D., Zhu, Q. H., Li, M., Chen, H., Guo, Y., Fan, L. P., Yue, L. S., Li, L. Y., \& Zhao, M. (2016). Rutin ameliorates kidney interstitial fibrosis in rats with obstructive nephropathy. International Immunopharmacology, 35, 77-84. http://dx.doi.org/10.1016/j. intimp.2016.03.029. PMid:27035719.

Wu, J., Maoqiang, L., Fan, H., Zhenyu, B., Qifang, H., Xuepeng, W., \& Liulong, Z. (2016). Rutin attenuates neuroinflammation in spinal cord injury rats. The Journal of Surgical Research, 6(March), 1-7. http://dx.doi.org/10.1016/j.jss.2016.02.041. PMid:27363641.

Xu, P., Wang, S. W., Yu, X. L., Su, Y. J., Wang, T., Zhou, W. W., Zhang, H., Wang, Y. J., \& Liu, R. T. (2014). Rutin improves spatial memory in Alzheimer's disease transgenic mice by reducing $\mathrm{AB}$ oligomer level and attenuating oxidative stress and neuroinflammation. Behavioural Brain Research, 264, 173-180. http://dx.doi.org/10.1016/j. bbr.2014.02.002. PMid:24512768.

Yorulmaz, A., Poyrazoglu, E. S., Ozcan, M. M., \& Tekin, A. (2012). Phenolic profiles of Turkish olives and olive oils. European Journal of Lipid Science and Technology, 114(9), 1083-1093. http://dx.doi. org/10.1002/ejlt.201100186. 